\title{
Effect of acid treatment in alcoholic fermentation
}

\author{
Efeitos do tratamento ácido na fermentação alcoólica
}

\author{
Rosiane de Souza Silva ${ }^{* 1}$, Poliane Alves de Oliveira ${ }^{2}$, Élica Renata Soares da Silva ${ }^{3}$, \\ Cláudia Andéa Lima Cardoso ${ }^{4}$, José Roberto Ernandes ${ }^{5}$ e Margareth Batistote ${ }^{6}$ \\ 1,2,3 Graduanda,Universidade Estadual do Mato Grosso do Sul - UEMS- Brasil \\ ${ }^{4}$ Mestranda,Universidade Estadual do Mato Grosso do Sul - UEMS- Brasil \\ 5,6 Professores,Universidade Estadual do Mato Grosso do Sul - UEMS- Brasil
}

\begin{abstract}
The fermentation process in Brazil is characterized by intense cell recycle resulting in high cell density fermentation process. After fermentation the yeast is collected and centrifuged, and subjected to acid pH 2.0 during 2.0 hour treatment, these conditions are stressful for yeast. The study aims to evaluate the physiological effects of the action of acid treatments in different industrial strains of S. cerevisiael. Synthetic medium YPSAC 15\% was used for the production of biomass cell for three recycles and treatment with nitric, hydrochloric and sulfuric acids for two hours. The higher biomass production occurred in the treatment with sulfuric acid in three consecutive cycles . In the presence of nitric acid was little loss of biomass and in the presence of hydrochloric acid was the major loss of biomass. The strain Catanduva 1 exhibited the highest cell viability in nitric acid in all the cycles analyzed and the lower rate of cell viability was observed in the presence of sulfuric acid in the third cycle. The treatment with hydrochloric acid in cell viability loss occurred in all cycles analyzed. In synthetic medium showed a higher accumulation of ethanol concentration in the third cycle fermentation. Treatment with nitric acid showed the highest concentrations of ethanol in the first and second cycles. In the presence of sulfuric acid occurred the lowest concentration of ethanol. On the treatment with hydrochloric acid occurred a variation of ethanol in all the cycles analyzed.
\end{abstract}

Keywords: Fermentative parameters. Metabolism. Yeast.

\section{Resumo}

O processo fermentativo brasileiro é caracterizado por um intenso reciclo de células resultando em alta densidade celular no processo fermentativo. Após a fermentação, as leveduras são coletadas e centrifugadas, e submetidas ao tratamento ácido em pH 2,0 por 2,0 horas, estas condições são estressantes para as leveduras. O trabalho visa avaliar os efeitos fisiológicos da ação de diferentes tratamentos ácidos em linhagens de S. cerevisiae industriais. Utilizou-se o meio sintético YPSAC a 15\% na produção de biomassa celular por três reciclos, e tratamento com os ácidos nítrico, clorídrico e sulfúrico por duas horas. A maior produção de biomassa ocorreu no tratamento com o ácido sulfúrico, que se manteve nos três ciclos consecutivos. Na presença do ácido nítrico ocorreu uma pequena perda de biomassa e na presença de ácido clorídrico ocorreu a maior perda de biomassa. A linhagem Catanduva 1 apresentou a maior viabilidade celular em ácido nítrico em todos os ciclos analisados e a menor taxa de viabilidade celular foi observada na presença do ácido sulfúrico no terceiro ciclo.No tratamento com ácido clorídrico ocorreu perda da viabilidade celular em todos os ciclos analisados. O meio sintético apresentou um maior acúmulo da concentração de etanol no terceiro ciclo fermentativo.O tratamento com ácido nítrico apresentou as maiores concentrações de etanol no primeiro e segundo ciclos. Na presença do ácido sulfúrico ocorreu a menor concentração de etanol. No tratamento com o ácido clorídrico ocorreu uma variação de etanol nos ciclos analisados

Palavras-chave: Parâmetros fermentativos. Metabolismo. Leveduras. 


\section{Introduction}

$\mathrm{T}$ he ethanol fuel production in Brazil differs dramatically from other industrial fermentations. There are two peculiarities regarding this type of fermentation: the first is that the must is not subjected to a pretreatment for removing the native microbiota in sugar cane, and second is that there are more fermentative cycles.

Lately, large volumes of Saccharomyces cerevisiae strains are isolated during the fermentation process in Brazilian distilleries and have been used as pre-inoculum in various industrial units. After the characterizations as good fermentations capable and dominate its process of all the harvest, they are used as biomass in the unit that was isolated, as in the others units. These strains were then named after the initials of their units in which they were isolated as: BG-1 (Barra Grande), CR-1 (Cresciumal), SA-1 (Santa Adelia), CAT-1 (Catanduva ), PE-2 (Pedra).

Thus, the use of isolated yeasts in the process and subsequent selection is a viable alternative in the initiation of the Industrial season (AMORIM, 2005; ANDRIETTA et al., 2007).

One of the major technological advances in the fermentation process in Brazil was the introduction of Melle-Boinot system that consists in fermentations with high cell density and recycling of yeast. In this system, the baking passed through continuous centrifuges, separating the yeast from fermented wort being distilled. These cells recovered were termed as "foot-bowl", or pre-inoculum, and to follow subsequent treatment and purification, thus being reused in subsequent cycles in the production of fuel alcohol (AMORIM, 2005).

The acid treatment is usually employed as a means to control contamination and promote deflocculating of the yeast (OTÊNIO, 1998). In Brazil, sulfuric acid is used in the fermentation process (LALUCE et al., 1990). According to Cartwright et al. (1989), the mechanism in which the acids presented in the fermentation act depends on the $\mathrm{pH}$ value. The use of low $\mathrm{pH}(2.0-2.5)$ may affect the metabolism of the yeast (LUDWIG et al., 2001; FURTADO and SCANDIFFIO, 2006)

This study determined the physiological effects of different treatments acids in strains of $S$. cerevisiae used in ethanol production.

\section{Material and Methods}

\subsection{Strain used}

The strain studied (Catanduva 1) was obtained through the LNF Company, Latin American Applied Biotechnology, located at; Street Fioravante Pozza, 198 - Bento Gonçalves, RS, Brazil.

\subsection{Cell growth}

To obtain cell mass, it was used classical cultivation medium YPSAC $5 \%$, containing $(1.0 \%(\mathrm{w} / \mathrm{v})$ yeast extract, $1.0 \%(\mathrm{w} / \mathrm{v})$ peptone, $5.0 \%(\mathrm{w} / \mathrm{v})$ sucrose), with $\mathrm{pH}$ adjusted to 5.0 with hydrochloric acid $(1 \mathrm{~N})$ and sterilized in an autoclave at $120^{\circ} \mathrm{C}$ for 20 minutes. The flasks containing yeast cells were incubated in "shaker" type $\mathrm{CT}-712 \mathrm{R}, 30^{\circ} \mathrm{C}$ for $24 \mathrm{~h}$ at $250 \mathrm{rpm}$. After growth cells were collected by centrifugation $(800 \mathrm{~g}, 20 \mathrm{~min}$.), suspended and washed three consecutive times in saline $(0.85 \%)$ sterile, at a concentration of $10 \mathrm{mg} / \mathrm{mL}$.

\subsection{Experiment fermentative}

For the preparation of the pre-inoculum, a medium classical cultivation was used; YPSAC 5\%, comprising $1.0 \%(\mathrm{w} / \mathrm{v})$ yeast extract, $1.0 \%(\mathrm{w} / \mathrm{v})$ peptone, $5.0 \%(\mathrm{w} / \mathrm{v})$ sucrose, with $\mathrm{pH}$ adjusted to 5.0 with hydrochloric acid (1N) and sterilized in an autoclave at $120^{\circ} \mathrm{C}$ for $20 \mathrm{mi}-$ nutes. The flasks containing yeast cells were incubated in "shaker" type CT-712R, $30^{\circ} \mathrm{C}$ for $24 \mathrm{~h}$ at $250 \mathrm{rpm}$. Fermentation assays were performed in $125 \mathrm{~mL}$ flasks, containing synthetic medium YPSAC $15 \%$, with $\mathrm{pH}$ adjusted to 5.0 hydrochloric acid $(1 \mathrm{~N})$ and sterilized in an autoclave at $120^{\circ} \mathrm{C}$ for 20 minutes. The flasks were incubated at $30^{\circ} \mathrm{C}$ without stirring in an oven. For each fermentation period of 8 hours, samples were removed for analysis of fermentation parameters such as biomass, viability and ethanol.

\subsection{Acid treatment}

After each fermentation period the cells were washed and centrifuged $(800 \mathrm{~g}, 20 \mathrm{~min})$, and washed in saline $(0.85 \%)$ sterile, cell mass was inoculated in $50 \mathrm{~mL}$ of acids (sulfuric, hydrochloric and nitric $2 \mathrm{~N}$ ), and were incubated for two hours, each in a period of 2 hours samples were removed for analysis of fermentative parameters.

\subsection{Parameters fermentative}

the biomass analyzed was performed by spectrophotometric measurements at $570 \mathrm{~nm}$, correlated with the calibration curve. And the determination of cell viability was monitored determined by the method of staining with methylene blue (LEE et al., 1981).

Ethanol concentration was determined in GC 3900 gas chromatograph with flame ionization detector (Varian), using a fused silica capillary column of $30 \mathrm{~m}$ length (ZB5). The chromatographic conditions were employed: $1 \mu \mathrm{L}$ injection volume, split ratio 1:20, and oven temperature of $90^{\circ} \mathrm{C}$. The temperatures of the injector and detector were $240^{\circ} \mathrm{C}$. The samples were filtered through ultra filter 0.22 micrometers. 


\section{Results and Discussion}

The Catanduva- 1 is one of the most widely used yeasts in the southern state of Mato Grosso do Sul (BATISTOTE et al., 2010), and also in Brazil's industrial parks.

Studies on the effect of different acids treatments in yeast are important because during the fermentation processes this treatment is used to decontaminate the yeast. The search for more efficient fermentation processes in order to better understand the metabolic capacity of the yeasts are important to promote better efficiency of fermentation processes and therefore improve ethanol production.

Figures 1 to 3 illustrate the fermentative parameters Catanduva-1 grown in synthetic medium YPSAC 15\% $(\mathrm{w} / \mathrm{v})$, fermenting for three cycles with intervals of 2 hours for acid treatment. The analyzes show that the strain showed differences in fermentation characteristics in relation to the parameters analyzed in the presence of different acids.

Biomass production in synthetic medium showed better cell growth in eight hours of fermentation in the first cycle having a fermentation biomass of $12 \mathrm{mg} / \mathrm{mL}$. In fermentative cycles 2 and 3, gradual loss of biomass occurred. Biomass production in the presence of different acids showed differences, greater biomass was in the presence of sulfuric acid at $10 \mathrm{mg} / \mathrm{mL}$ in the first cycle of treatment. This biomass remained higher in three consecutive cycles. In the presence of nitric acid there was little loss of biomass cycles analyzed. The largest reduction in biomass was in the presence of hydrochloric acid in all the cycles analyzed

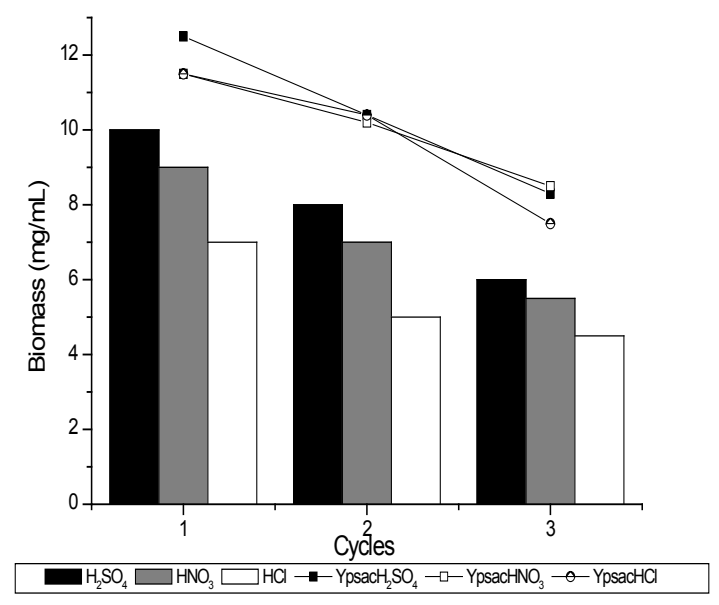

Figure 1: Biomass Catanduva 1 in YPSAC 15\% (w/v) in the presence of sulfuric, nitric and hydrochloric acids at a concentration $(2 \mathrm{~N})$ for three consecutive cycles fermentation.

Sulfuric acid is widely used in the fermentation process; Melle-Boinot system is adopted in almost all companies producing ethanol in Brazil. This acid plays a fundamental role in acidification of the environment, making the environment unfavorable for bacterial contaminants. Sulfuric acid is also the main item responsible for inhibition and cell death of $S$. cerevisiae (VENTURA, 2009).

The higher percentage of cell viability in YPSAC15\% $(\mathrm{w} / \mathrm{v})$ occurred in the first fermentation cycle, approximately $98 \%$ and also showed the lowest rate in the third cycle. Cell viability showed similarities with respect to the second and third cycle. In the treatment with nitric acid lineage Catanduva-1 showed the highest viability rate in all cycles analyzed. The cellular viability lower is obtained in sulfuric acid in the third cycle. In the acid treatment there was a small loss in cell viability in all cycles (Fig. 2).

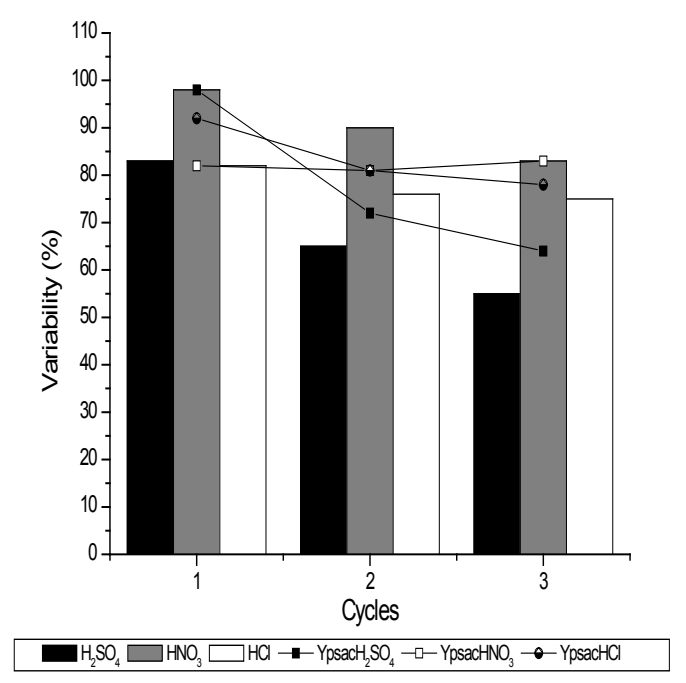

Figure 2: Cell viability Catanduva 1 in YPSAC15\% (w/v) in the presence of sulfuric, nitric and hydrochloric acids at a concentration of $(2 \mathrm{~N})$ by three consecutive cycles fermentation.

In distillery, yeasts are separated by centrifugation of the most. Then the yeast is subjected to a treatment with sulfuric acid before being submitted to a new fermentation (SILVA-FILHO et al., 2005). This can compromise the viability of the cells and therefore cause a decrease in the yield of fermentation (BROSNAN et al., 2000; BASSO and AMORIM 2008).

The ethanol concentration of the Catanduva strain 1 in YPSAC $15 \%(\mathrm{w} / \mathrm{v})$, presented a gradual accumulation of ethanol concentration in all cycles tested, having the highest accumulation concentration in the fermentation in the third cycle of $12 \%(\mathrm{v} / \mathrm{v})$ ethanol. The treatment with nitric acid had the highest concentration of ethanol during the first cycle of $9 \%(\mathrm{v} / \mathrm{v})$. The treatment in the presence of sulfuric acid which occurred was the lowest concentration of ethanol; this gradual loss was higher in the third cycle in a concentration of $5.5 \%(\mathrm{v} / \mathrm{v})$ ethanol. The ethanol concentration in hydrochloric acid was 
similar in cycles 1 and 2 and higher in the third cycle.

The process showed a gradual loss of ethanol concentration in the sulfuric acid treatment being the lowest concentration of ethanol on the third cycle fermentation (Fig. 3).

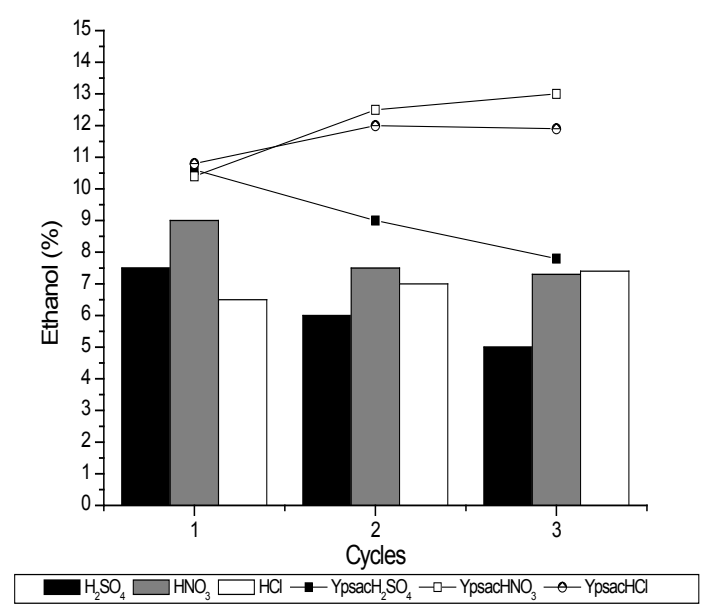

Figure 3: Ethanol Catanduva 1 in YPSAC15\% (w/v) in the presence of sulfuric, nitric and hydrochloric acids at a concentration of $(2 \mathrm{~N})$ by three consecutive cycles fermentation.

BATISTOTE et al. (2010) analyzed Catanduva-1 strains and Pedra-2 used in Mato Grosso do Sul, grown in must the base for sugar cane juice concentration of $15^{\circ}$ Brix and Catanduva strain -1 showed the highest ethanol concentration of $16 \%(\mathrm{v} / \mathrm{v})$ in 16 hours of fermentation.

In distilleries, yeasts are separated by centrifuging the wort. Then the yeast is subjected to an acid wash ( $\mathrm{pH}$ 2.0) with commercial sulfuric acid before being subjected to a further fermentation (SILVA-FILHO et al., 2005). This can compromise the viability of the cells and therefore cause a decrease in the yield of fermentation (NAGASHIMA, 1990; BROSNAN et al., 2000).

Although the acid wash used in distilleries is a stress factor (WHEALS et al., 1999; BROSNAN et al., 2000), it is still unclear how the inorganic acids affect the viability of yeast cells (CHENG et al., 1999). Saccharomyces cerevisiae is more sensitive at the temperature of $47^{\circ} \mathrm{C}$ while hydrochloric acid is in the middle, but this sensitivity is greater in the presence of acetic acid. The effect of acid treatment depending on the thermo tolerance of intracellular $\mathrm{pH}$ is greater in the presence of hydrochloric acid (CARMELO et al., 1998).

\section{Conclusions}

The Catanduva 1 strain subjected to acid treatments showed differences in the fermentation profile. The treatment with nitric acid showed a higher cell viability and concentration of ethanol compared to the other acids tested.

\section{Acknowledgements}

The authors wish to thank FUNDECT-MS, CNPq and LNF.

\section{References}

AMORIM, V.A. Fermentação alcoólica: ciência e tecnologia. Piracicaba: FERMENTEC, p. 434, 2005.

ANDRIETTA, M.G.S; STECKELBERG, C.E ANDRIETTA S.R.Bioetonol - Brasil 30 anos na vanguarda. MultiCiências, v. 35, n. 2, p. 1-16 2006.

ANDRIETTA, M.G.S.; ANDRIETTA, S.R.; STECKELBERG, C. STUPIELLO, E.N.A. Bioethanol - 30 years of Proálcool, International Sugar Journal, v. 109, p. 195-200, 2007.

BATISTOTE, M; .; CRUZ, S.H.; ERNANDES, J.R., Altered patterns of maltose and glucose fermentation by brewing and wine strains influenced by the complexity of the nitrogen source. Journal of the Institute of Brewing, v. 112, p. 84-91, 2006.

BATISTOTE, M.; CARDOSO, L.C.; ERNANDES, J. R.; RAMOS, D.D. Desempenho de leveduras obtidas em indústrias de Mato Grosso do Sul na produção de etanol em mosto a base de cana de açúcar, Revista Ciência Natura, v. 32, n. 2, p. 83-95, 2010.

BASSO, L.C.; AMORIM, H.V.. Yeast selection for fuel ethanol production in Brazil. FEMS Yeast Research, $\mathrm{V}$. 8, p. 1155-63,_2008.

BOVI, R.; MARQUES, M.O. O tratamento ácido na fermentação alcoólica. STAB Álcool e Açúcar, v. 3, n. 9, p. 10-13, 1982.

BROSNAN, M.P.; DONNELLY, D.; JAMES, T.C; BOND, U. The stress repressed during fermentation im brewery strains of yeast. Journal Applied Microbiology, v. 88, n. 5, p. 746-755, 2000.

CARMELO, V.; SANTOS, R.; VIEGAS and SÁ-CORREIA, I. Modification of Saccharomyces cerevisae thermotolerance following rapid exposure to acid stress. International Journal of food Microbilogy, v. 42, p. 225-230, 1998.

CARTWRIGHT, C.P.; ROSE, A.H.; CALDERBANK, J.; KEENAN, M.H.J. Solute Transport. In: A.H. ROSE, editor. The Yeasts. Academic Press, London, v. 3, p. 5-56, 1989. 
CHENG, L.; MOGHRABY, J.; PIPER, P.W. Weak organic acid treatment causes a trehalose accumulation in low$\mathrm{pH}$ cultures of Saccharomyces cerevisae, not displayed by the more preservative-resistant Zygosaccharomyces bailli. FEMS Microbiology Letters, v. 170, p. 89-95, 1999.

FURTADO, T.A.; SCANDAFFIO, M. G. Álcool do Brasil - uma longa história. Scientific American Brasil, n. 53, p. 66-71, 2006.

LEE, S. S.; ROBINSON, F. M.; WANG, H. Y.; Rapid determination of yeast viability. Biotechnology Bioengineering Symposium, v. 11, p. 641-649, 1981.

LALUCE, C.; PALMIERI, M.C.; CRUZ, C.L. Growth and fermentation characteristics of new selected strains of Saccharomyces at high temperatures and high cell densities. Biotechnological Bioenergy, v. 37, n. 6, p. 528-536, 1990.

LUDWIG, K.M.; OLIVA-NETO, P.; ANGELIS, D.F. Quantificação da floculação de Saccharomyces cerevisiae por bactérias contaminantes da fermentação alcoólica. Ciência Tecnologia Alimentos, Campinas, v. 21, n. 1, p. 63-68, 2001.

MESSIAS, Jr. M.; BATISTOTE., M.; CILLI, M.F.; ERNADES, J.R. Sucrose fermentation by Brazilian ethanol production yeasts in media containing structurally complex nitrogen sources. Journal of the Institute of Brewing, v. 115, n. 3, p. 191-197, 2009.

NAGASHIMA, M. Progress in ethanol production with yeasts. In: H. Verachtert and R. De Mot, editor. Yeast: biotechonology and Biocatalysis. New York, Marcel Dekkerinc, p. 3-84, 1990.

OTÊNIO, M.H. Avaliação comparativa do efeito da retirada do tratamento ácido com ácido sulfúrico no fermento durante os reciclos, na Usina Bandeirantes, PR, na rotina industrial da Destilaria Anexa. (Dissertação) Universidade Estadual Paulista (UNESP), Rio Claro, 1998.

SILVA-FILHO, E.A.; SANTOS, S.K.B.; RESENDE, A.M.; MORAIS, J.O.F.; MORAIS Jr., M.A.; SIMOES, D. A. Yeast population dynamics of industrial fuel ethanol fermentation process assessed by PCR-fingerprinting. Atonie Van Leeuwenhook, v. 88, p. 13-23, 2005.

VENTURA, R. Potenciais Contaminantes em Levedura Extraída de Fermentação Alcoólica. 2009. Disponível em: http://www.quimicareal.com.br/upload/palestra ventura.pdf Acesso em: 17 de jun. de 2010.

WHEALS, E.A.; BASSO, L.C.; ALVES, D.M.G.; AMORRIM, H.V. Fuel ethanol after 25 years. Trends in Biotechnololy, v. 17, p. 482-487, 1999. 